\title{
The Impact of Micro Credit Institutions on the Development of Small and Medium Enterprises in Anambra State
}

\author{
Ndife, Chinelo Franca \\ Department of Business Administration Federal Polytechnic Oko, Anambra State, Nigeria
}

\begin{abstract}
This research on the effect of microcredit institutions on the development of small and medium scale enterprises (SMEs) in Anambra State was aimed at determining the impact of microcredit institutions in starting up, survival and growth of SMEs as well as the effect collateral requirements in obtaining loans from microcredit institution in Anambra South and North senatorial district of Anambra State. A sample of 450 respondents was selected for the work using the judgmental and systematic random sampling methods. Although a significant relationship were observed to exist between microcredit institutions and SMEs development, the small degree of association that exist suggests that capital (microcredit) is not the only factor that affect SMEs in the study population.
\end{abstract}

Keyword: SMEs, Microcredit, small scale business, SME financing

\section{Introduction}

Micro credit consists of small loans provided to micro enterprises. Microcredit dates back in the 19th century when money lenders were informally performing the role now played by financial institutions. The informal financial institutions constitute; village banks, cooperative credit unions, state owned banks, and social venture capital funds to help the poor.

More recently, commentators have commented on the critical role of micro-credit in achieving the Millennium Development Goals, since they mobilize rural savings and have simple and straight forward procedures that originate from local cultures and are easily understood by the populace. These funds are to provide credit the informal sector SMEs in developing countries[1,2,3,4]

Small and Medium Enterprises (SMEs) are commonly believed to have very limited access to deposits, credit facilities and other financial support services provided by Formal Financial Institutions (FFIs). As Quaye [5] argues that this is because these SMEs cannot provide the necessary collateral security demanded by these formal institutions and also, the banks find it difficult to recover the high cost involved in dealing with small firms. In addition to this, the associated risks involved in lending to MSEs make it unattractive to the banks to deal with micro and small enterprises.

In Nigeria, credit has been recognized as an essential tool for promoting small and Micro Enterprises (SMEs) and about 70 percent of the population is engaged in the informal sector or in agricultural production and that Federal and State governments have recognized that for sustainable growth and development, the financial empowerment of the people is vital. If this growth strategy is adopted and the latent entrepreneurial capabilities of this large segment of the people is sufficiently stimulated and sustained, then positive multipliers will be felt throughout the economy [6].

The Micro business entrepreneurs lack the necessary financial services, especially credit from the commercial banks; this is because they are considered not credit worthy. Consequently they depended on families, friends and other informal sources of funds to credit their businesses.

\section{Statement Of The Problem}

The challenges faced by small and medium enterprises (SMEs) in Nigeria are majorly that of financing. In Anambra state for example access to fund has posed major challenge for starting up, survival and growth of SMEs. Lack of access of small and medium scale enterprises to credit has hampered their contribution to economic growth and development as it has affected the setting up, growth and survival of SME's The thrust of this work therefore is to evaluate the impact of micro credit institutions on the development of small and medium enterprises in the two senatorial districts (Anambra North and Anambra South) of Anambra state, Nigeria.

\section{Objective Of The Study}

The general objective of this study is to assess the relevance of Micro Credit Institutions on the development of Small and Medium enterprises in two senatorial zones (Anambra South and Anambra North) of Anambra state, Nigeria.

The specific objectives of the study include the following: 
- To ascertain the effect of micro credit Institutions on setting up of new business

- To assess the effect of Micro Credit Institutions on survival of SME's Anambra state.

- To determine the effect of Micro Credit Institutions on growth of SME's in Anambra State.

- To ascertain the impact of collateral requirements on SMEs in obtaining credit facilities from Micro credit institutions

\section{Reseearch Hypothesis}

- $\mathrm{H}_{0}$ : micro credit Institutions do not have significant impact on setting up of new business

- $\mathrm{H}_{0}$ : Micro Credit Institutions do not have significant effect on survival of SME's Anambra state.

- $\mathrm{H}_{0}$ : Micro Credit Institutions do not have significant effect on growth of SME's in Anambra State.

- $\mathrm{H}_{0}$ : collateral requirement on SMEs do not have significant effect on obtaining credit facilities from Micro credit institutions

\section{Review Of Related Literature}

This study is anchored on the transaction cost theory. Transaction cost approach to the theory of the firm was created by Ronald Coase[7] in his article "The Problem of Social Cost" "In order to carry out a market transaction it is necessary to discover who it is that one wishes to deal with, to conduct negotiations leading up to a bargain, to draw up the contract, to undertake the inspection needed to make sure that the terms of the contract are being observed, and so on".

The transaction cost according to Bhatt and Shui-Yan[8] can be conceptualized as a non financial cost incurred in credit delivery by the borrower and the lender before, during and after the disbursement of loan. The cost incurred by the lender includes; cost of searching for funds to loan, cost of designing credit contracts, cost of screening borrowers, assessing project feasibility, cost of scrutinizing loan application, cost of providing credit training to staff and borrowers, and the cost of monitoring and putting into effect loan contracts. On the other hand, the borrowers that is MSEs for this case may incur cost ranging from cost associated in screening group member (group borrowing), cost of forming a group, cost of negotiating with the lender, cost of filling paper work, transportation to and from the financial institution, cost of time spent on project appraisal and cost of attending meetings, etc. The parties involved in a project will determine the transaction cost rate. They have the sole responsibility to reduce the risk they may come across[9].

Quaye[5] while studying the effects of Microcredit Institution (MFIs) on the growth of Small and Medium Scale Enterprises (SMEs), examined the detailed profile of SMEs in the Kumasi Metropolis of Ghana, reveals that Micro credit institutions have a positive effect on the growth SMEs. In other to enhance a sustained and accelerated growth in the operations of SMEs credits should be client-oriented and not product- oriented. Proper and extensive monitoring activities should be provided for clients who are granted loans.

Chijoriga[10] evaluated the performance and financial sustainability of MFIs in Tanzania, in terms of the overall institutional and organizational strength, client outreach, and operational and financial performance.28 MFIs and 194 MSEs were randomly selected and visited in Dar es Salaam, Arusha, Morogoro, Mbeya and Zanzibar regions. The findings of this revealed that, the overall performance of MFIs in Tanzania is poor and only few of them have clear objectives, or a strong organizational structure. It was further observed that MFIs in Tanzania lack participatory ownership and many are donor driven. Although client outreach is increasing, with branches opening in almost all regions of the Tanzanian mainland, still MFIs activities remain in and around urban areas. Their operational performance demonstrates low loan repayment rates. In conclusion, the author pointed to low population density, poor infrastructures and low house hold income levels as constraints to the MFIs' performance.

Amin et al[11] used a unique panel dataset from northern Bangladesh with monthly consumption and income data for 229 households before they received loans. They find that while microcredit is successful in reaching the poor, it is less successful in reaching the vulnerable, especially the group most prone to destitution (the vulnerable poor).

Coleman[12] also finds little evidence of an impact on the programme participants. The results, Coleman further explains, are consistent with Adams and von Pischke's assertion that "debt is not an effective tool for helping most poor people enhance their economic condition" and that the poor are poor because of reasons other than lack of access to credit.

Abiola[13] in his paper, Impact Analysis of Microcredit in Nigeria applies the financing constraints approach to study whether microcredit institutions improved access to credit for microenterprises in Nigeria or not. According to this approach, microenterprises with improved access to credit rely less on internal funds for their investments. Thus, investment sensitivity to internal funds of microenterprises in Lagos State (a municipal with significant presence of Microcredit Banks was compared to that of micro enterprises in Ekiti State (a municipal with no (or limited) presence of s) using a cross sectional survey method and Microcredit Institutions 
(MFI) branch location data. Results indicate that s alleviated micro businesses' financing constraints. This approach is applicable to evaluating microcredit impact in other countries.

Based on the above contributions of scholars on this topic, this work however, tries to study the Nigerian environment, particularly the three senatorial districts of Anambra state.

\section{Reasearch Methodology}

The primary source of data was used for this research. Structured questionnaires were used to obtain information from the respondents. The questionnaires have sections comprising of Demographic information of respondents and impact of microcredit institutions on development of SME's in Anambra State. The questionnaires were administered and retrieved after two working days. This was to give the respondents enough time to answer the questions.

The judgemental sampling method was used to select the senatorial districts and towns studied. The towns selected include: Onitsha, Nkpor, Nnewi, ogidi, Obosi, Umunya. The towns were selected based on their dominance of SMEs. A systematic sampling method was then used to select the SMEs that were interviewed since a comprehensive list of SMEs is not available. Systematic Random Sample is a Random Sample obtained by selecting the first elementary unit of the population on a random basis and then choosing subsequent elementary unit at evenly spaced interval until the desire number of units are drown. The author also noted that systematic samples are easier to draw without mistakes[14,15].

In accomplishing this, the first elementary unit (artisan) was drawn from each business cluster using a simple random sampling method and every other fifth unit was drawn. Three top management staff were selected from each medium scale enterprise since they are well disposed to give information regarding the companies source of fund.

The population comprised of all SMEs in Anambra South and Anambra North Senatorial district of Anambra State. A sample of 450 SMEs was selected for the study.

The chi-square test was used in testing the hypotheses that the variables of classification are independent. Whenever a significant relationship exist between variables, there is need to measure the degree of relationship by using the formula of coefficient of contingency[16]

\section{Hypothesis Testing}

\section{Hypothesis 1.}

$\mathbf{H}_{\mathbf{0}}$ : micro credit Institutions do not have significant impact on setting up of SMEs

The resulting contingency table is given below 1

Table 1: contingency table of effect of microcredit institutions and business start-up. The expected values are in parenthesis ()

\begin{tabular}{|c|c|c|c|c|c|c|}
\hline & \multicolumn{5}{|c|}{ BUSINESS START-UP } & \\
\hline $\begin{array}{c}\text { MICRO CREDIT } \\
\text { INSTITUION }\end{array}$ & SD & $\mathbf{D}$ & $\mathbf{U}$ & $\mathbf{A}$ & SA & ROW TOTAL \\
\hline QUS 1 & $108(99.4)$ & $86(117.2)$ & $16(21.8)$ & $66(56.2)$ & $84(65.4)$ & 360 \\
\hline QUS 2 & $71(99.4)$ & $122(117.2)$ & $24(21.8)$ & $65(56.2)$ & $78(65.4)$ & 360 \\
\hline QUS 3 & $99(99.4)$ & $117(117.2)$ & $21(21.8)$ & $54(56.2)$ & $69(65.4)$ & 360 \\
\hline QUS 4 & $107(99.4)$ & $135(117.2)$ & $34(21.8)$ & $47(56.2)$ & $37(65.4)$ & 360 \\
\hline QUS 5 & $112(99.4)$ & $126(117.2)$ & $14(21.8)$ & $49(56.2)$ & $59(65.4)$ & 360 \\
\hline TOTAL & $\mathbf{4 9 7}$ & $\mathbf{5 8 6}$ & $\mathbf{1 0 9}$ & $\mathbf{2 8 1}$ & $\mathbf{3 2 7}$ & $\mathbf{1 8 0 0}$ \\
\hline
\end{tabular}

Source: field research 2013

The result obtained at $5 \%$ level of significance is: $\mathrm{X}_{\text {cal }}^{2}=60.794$ and $\mathrm{X}_{\text {tab }}^{2}=26.30$

Decision: since $\mathrm{X}_{\text {cal }}^{2}=60.794$ is greater than $\mathrm{X}_{\text {tab }}^{2}=26.30$, reject $\mathrm{H}_{0}$ and conclude that a significant relationship exist between activities of microcredit institutions and SMEs growth

The contingency coefficient is $\sqrt{\frac{60.794}{60.794+1800}}=\sqrt{\frac{60.794}{60.794+1800}}=0.1808$

Expressing the value in percentage gives $0.1808 \times 100=18.08 \%$

Hypothesis 2.

$\mathbf{H}_{0}$ : micro credit Institutions do not have significant effect on survival of SME's Anambra state. 
The resulting contingency table is given below in table 2

Table 2: contingency table of effect of microcredit institutions SMEs survival. The expected values are in parenthesis ()

\begin{tabular}{|c|c|c|c|c|c|c|}
\hline \multirow[b]{2}{*}{ MICRO CREDIT INSTITUION } & \multicolumn{5}{|c|}{ BUSINESS SURVUVAL } & \multirow[b]{2}{*}{ ROW TOTAL } \\
\hline & SD & D & $\mathbf{U}$ & $\mathbf{A}$ & SA & \\
\hline QUS 1 & $45(54)$ & $58(56.6)$ & $25(17.2)$ & $150(121.6)$ & $82(110.6)$ & 360 \\
\hline QUS 2 & $79(54)$ & $79(56.6)$ & $16(17.2)$ & $82(121.6)$ & $104(110.6)$ & 360 \\
\hline QUS 3 & $46(54)$ & $48(56.6)$ & $12(17.2)$ & $154(121.6)$ & $100(110.6)$ & 360 \\
\hline QUS 4 & $59(54)$ & $40(56.6)$ & $23(17.2)$ & $98(121.6)$ & $140(110.6)$ & 360 \\
\hline QUS 5 & $41(54)$ & $58(56.6)$ & $10(17.2)$ & $124(121.6)$ & $127(110.6)$ & 360 \\
\hline TOTAL & $\mathbf{0}$ & $\mathbf{0}$ & $\mathbf{0}$ & $\mathbf{0}$ & $\mathbf{0}$ & 1800 \\
\hline
\end{tabular}

The result obtained at $5 \%$ level of significance is: $\mathrm{X}_{\mathrm{cal}}^{2}=94.966$ and $\mathrm{X}_{\mathrm{tab}}^{2}=26.30$

Decision: since $\mathrm{X}_{\text {cal }}^{2}=94.966$ is greater than $\mathrm{X}_{\text {tab }}^{2}=26.30$, reject $\mathrm{H}_{0}$ and conclude that a significant relationship exist between activities of microcredit institutions and SMEs survival

The contingency coefficient is $\sqrt{\frac{94.966}{94.966+1800}}=\sqrt{\frac{94.966}{1894.966}}=0.2238$

Expressing the value in percentage gives $0.2238 \times 100=22.38 \%$

Hypothesis 3.

$\mathbf{H}_{\mathbf{0}}$ : micro credit Institutions do not have significant effect on growth of SME's Anambra state.

The resulting contingency table is given below in table 3

Table 3: contingency table of effect of microcredit institutions SMEs growth. The expected values are in parenthesis 0

\begin{tabular}{|c|c|c|c|c|c|c|}
\hline & \multicolumn{5}{|c|}{ BUSINESS GROWTH } & \\
\hline $\begin{array}{c}\text { MICRO CREDIT } \\
\text { INSTITUION }\end{array}$ & SD & D & U & A & SA & ROW TOTAL \\
\hline QUS 1 & $81(91)$ & $122(106.4)$ & $14(12.2)$ & $66(76.8)$ & $77(73.6)$ & 360 \\
\hline QUS 2 & $119(91)$ & $109(106.4)$ & $16(12.2)$ & $55(76.8)$ & $61(73.6)$ & 360 \\
\hline QUS 3 & $89(91)$ & $92(106.4)$ & $13(12.2)$ & $79(76.8)$ & $87(73.6)$ & 360 \\
\hline QUS 4 & $68(91)$ & $125(106.4)$ & $9(12.2)$ & $85(76.8)$ & $73(73.6)$ & 360 \\
\hline QUS 5 & $98(91)$ & $84(106.4)$ & $9(12.2)$ & $99(76.8)$ & $70(73.6)$ & 360 \\
\hline Source: field research 2013 & $\mathbf{4 5 5}$ & $\mathbf{5 3 2}$ & $\mathbf{6 1}$ & $\mathbf{3 8 0}$ & $\mathbf{3 6 8}$ & $\mathbf{1 8 0 0}$ \\
\hline
\end{tabular}

The result obtained at $5 \%$ level of significance is: $\mathrm{X}_{\text {cal }}^{2}=51.554$ and $\mathrm{X}_{\text {tab }}^{2}=26.30$,

Decision: since $\mathrm{X}_{\text {cal }}^{2}=51.554$ is greater than $\mathrm{X}_{\text {tab }}^{2}=26.30$, reject $\mathrm{H}_{0}$ and conclude that a significant relationship exist between activities of microcredit institutions and SMEs growth

The contingency coefficient is $=\sqrt{\frac{51.554}{51.554+1800}}=\sqrt{\frac{51.554}{1851.554}}=0.1669$

Expressing the value in percentage gives $0.1669 \times 100=16.69 \%$

\section{Hypothesis 4.}

$\mathbf{H}_{\mathbf{0}}$ : collateral requirements on SMEs do not have significant effect on obtaining credit facilities from Micro credit institutions

The resulting contingency table is given below in table 4 
Table 4: contingency table of effect of collateral requirements on SMEs and obtaining microcredit facilities

\begin{tabular}{|c|c|c|c|c|c|c|}
\hline & \multicolumn{7}{|c|}{ COLLATERAL SECURITY } & \\
\hline $\begin{array}{c}\text { MICRO } \\
\text { CREDIT }\end{array}$ & SD & D & U & A & SA & ROW TOTAL \\
\hline QUS 1 & $45(74.8)$ & $49(85.6)$ & $11(12)$ & $156(96.8)$ & $99(90.8)$ & 360 \\
\hline QUS 2 & $113(74.8)$ & $126(85.6)$ & $14(12)$ & $48((96.8)$ & $59(90.8)$ & 360 \\
\hline QUS 3 & $108(74.8)$ & $86(85.6)$ & $16(12)$ & $66((96.8)$ & $84(90.8)$ & 360 \\
\hline QUS 4 & $68(74.8)$ & $117(85.6)$ & $9(12)$ & $85(96.8)$ & $81(90.8)$ & 360 \\
\hline QUS 5 & $40(74.8)$ & $50(85.6)$ & $10(12)$ & $129(96.8)$ & $131(90.8)$ & 360 \\
\hline TOTAL & $\mathbf{3 7 4}$ & $\mathbf{4 2 8}$ & $\mathbf{6 0}$ & $\mathbf{4 8 4}$ & $\mathbf{4 5 4}$ & $\mathbf{1 8 0 0}$ \\
\hline
\end{tabular}

The result obtained at $5 \%$ level of significance is: $\mathrm{X}_{\text {cal }}^{2}=240.799$ and $\mathrm{X}_{\text {tab }}^{2}=26.30$

Decision: since $\mathrm{X}_{\text {cal }}^{2}=240.799$ is greater than $\mathrm{X}_{\text {tab }}^{2}=26.30$, reject $\mathrm{H}_{0}$ and conclude collateral requirements on SMEs has significant effect on obtaining credit facilities from Micro credit institutions

The contingency coefficient is $=\sqrt{\frac{240.799}{240.799+1800}}=\sqrt{\frac{240.799}{2040.799}}=0.3435$

Expressing the value in percentage gives $0.3435 \times 100=34.35 \%$

\section{Analyses Of Findings}

This research 'The Impact of Micro Credit Institutions on the Development of Small and Medium Enterprises' was aimed at assessing the relevance of Micro Credit Institutions on the development of Small and Medium enterprises in two senatorial zones of Anambra state, Nigeria. Specifically, To ascertain the effect of micro credit Institutions on setting up, survival and growth of SME's in Anambra State as well as to ascertain the impact of collateral requirements on SMEs in obtaining credit facilities from Micro credit institution.

From the contingency coefficients computed, It was observed that $18.08 \%$ of success in staring up SMEs is attributable to microcredit institutions while $22.38 \%$ and $16.69 \%$ of SMEs survival and growth respectively are associated with microcredit institutions. Collateral requirement has about $34.35 \%$ effect in obtaining microcredit

The association observed to exist between microcredit institutions and SMEs development may be due to the fact that the development of any business is contingent upon many factors of which capital is one of them. The contingency coefficients computed show that Improving the activities of microcredit institutions to favour SMEs may increase the success of business start-ups to about $18.08 \%$, increase survival rates of business by $22.38 \%$, increase growth rate of business by $16.69 \%$ and vise visa, while relaxing the collateral requirements will facilitate borrowing from microcredit institutions to about $34.35 \%$ and tensing the collateral requirements will discourage borrowing from Micro credit institutions to $34.35 \%$.

\section{Conclusion}

This study has been able to show the relationships that exist between microcredit institutions and SMEs development in Anambra State. It is then necessary for microcredit institutions, SMEs and government to work together for the best interest of development of SMEs and Nigerian economy in general.

This study is necessary at this time owing to the efforts of governments at all level to create employment through self reliance especially in the areas of SMEs. If microcredit institutions' activities are found to have impact on the development of SMEs, then aiding the microcredit institutions will relax the tress of obtaining loans, thus making prospective entrepreneurs to willfully delve into small and medium scale business. This work will also add to existing literature on microcredit institutions and SMEs

\section{Recommendation}

Base on the findings of this work, the following recommendation will benefit both the microcredit institutions and SMEs

1. Government should help to reduce or totally remove interests on soft loans so as to make borrowing feasible.

2. The government should act as surety to SMEs when obtaining loans

3. In line with Abereijo and Fayomi (2005), Microcredit institutions should reduce their administrative/ transaction costs of lending. 


\section{Referrence}

[1]. Littlefield, E., Murduch, J. \& Hashemi, S. (2004). Is Microfinance an Effective Strategy to Reach the Millennium Development Goals?, Focus Note Series no. 24. Washington: CGAP -Consultative Group to Assist the Poor. 70

[2]. Simanowitz, A. and Brody, A. (2004). "Realizing the Potential of Microfinance", Insight: 51: 1-2

[3]. Germidis, Dimitri, Denis Kessler and Rachel Meghir (1991), Financial Systems and Development: What Role for the Formal and Informal Financial Sectors? Development Centre Studies. Paris: OECD

[4]. International Monetary Fund (2005). "Microfinance: A View from the Fund" IMF Paper, Washington DC

[5]. Quaye, D. O. (2011), "The Effect Of Micro Finance Institutions On The Growth Of Small And Medium Scale Enterprises (Smes); A Case Study Of Selected Smes In The Kumasi Metropolis

[6]. Olaitan M..A. (2006). Finance for Small and Medium Scale Enterprises in Nigeria. Journalof international farm management . 3(2)

[7]. Coase R.H (1960), 'The Problem of Social Cost, Journal of Law and Economics 1-44

[8]. Bhatt, N and Shui Yan T (1998). "The Problem of Transaction Costs in Group-Based Microlending: An Institutional Perspective." World Development.

[9]. Stiglitz J., (1990). "Peer monitoring and Credit Markets". The World Bank economic Review, World Bank, Washington DC. pp. 4,351-366.

[10]. Chijoriga, M. M. (2000) “The Performance and Sustainability of Micro Finance Institution in Tanzania” Working Paper.

[11]. Amin, Sajeda \& Rai, Ashok S. \& Topa, Giorgio, 2003. "Does microcredit reach the poor and vulnerable? Evidence from northern Bangladesh," Journal of Development Economics, Elsevier, vol. 70(1), pages 59-82, February.

[12]. Coleman, B.C. (1999) "The Impact of Group Lending in North East Thailand" Journal of Development Economics, Vol. 60, pp105141.6469

[13]. Abiola, B. (2011). Impact analysis of microfinance in Nigeria. International Journal of Economics and Finance, 3(4), 217-225

[14]. Igweze, A.H and Etaga H.O (2011): Statistical Analysis with Excel, Minitab and SPSS. Tualas Publishers, Asaba

[15]. Oyeka, I.C.A (1996): “An introduction to Applied Statistical Methods". Nobern Avocation Publishing Company, Enugu

[16]. Eze, J.I Obiebu M.E and Jude-Eze E.N (2005): Statistics and Quantitative Method for construction and business Managers. The Nigerian Institute of Building

[17]. Abereijo, I.O. and Fayomi A.O (2005). "Innovative Approach to SME Financing in Nigeria: A Review of Small and Medium Industries Equity Investment Scheme (SMIEIS). J. Soc. Sci., 11(3): 219-227 (2005). Accessible from http://www.krepublishers.com/02-Journals/JSS/JSS-11-0-000-000-2005-Web/JSS-11-3-173-258-2005-Abst-PDF/JSS-11-3219-227-2005-265-Abereijo-I-O/JSS-11-3-219-227-2005-265-Abereijo-I-O-Full-Text.pdf

\section{APPENDIX 1: QUESTIONNAIRE}

\section{SECTION A: DEMOGRAPHIC INFORMATION}

please tick $(\sqrt{ }$ )as appropriate

1. Gender ( ) Male ( ) Female

2. Age Of Respondence

3. Age Of Business

4. Scope / Type Of Business () Artisan () Small () Medium

5. $\quad$ Number Of Employees ( ) 1-5 ( ) 6-10 () 11-20 ( ) 21-30 ( ) 31-50 ( ) 50+

6. Net Annual Revenue From Business

( ) $10,000-50,000$ ( ) $51,000-100,000$ ( ) 101,000 -250,000

( ) 250,000-1000,000 ( )1000,000-2,000,000 ( ) Above 2,000,000

7. Have you ever obtained a loan from micro credit institutions? ( ) yes ( ) No

8. How Frequent Do You take loan From Micro Credit Banks

() Never () Once In Six Months () Once In A Year () Once In Two Years () Once In Five Years

9. Sources Of Fund () Savings () Borrow From Friends Borrow From family members () Borrow From Micro Credit Bank Institution

In each of the question below, kindly indicate your agreement of disagreement using the scale: Strongly Agree (SA); Agree (A); Undecided (UD); Disagree (D) and Strongly Disagree (SD)

\section{MICRO CREDIT INSTITUTIONS AND NEW BUSINESS START UP}

1. The money used for starting up business was partly / wholly borrowed from micro finance banks ( )

SA ( ) A ( ) UN ( ) D ( ) SD

2 . micro finance bank gave me the training needed to start this business

( ) SA ( ) A ( ) UN ( ) D ( ) SD

3. micro finance bank guided me on the area to invest

( ) SA ( ) A ( ) UN ( ) D ( ) SD

4. micro finance bank encouraged me to save to start my business

( ) SA ( ) A ( ) UN ( ) D ( ) SD

5. Micro credit institution do not insist on collateral when lending

( ) SA ( ) A ( ) UN ( ) D ( ) SD

MICRO CREDIT AND BUSINESS SURVIVAL

1. My business once had problem of finance

( ) SA ( ) A ( ) UN ( ) D ( ) SD

2. Micro credit institution had once saved my business from folding up 


\section{() SA () A () UN ( ) D ( ) SD}

3. Micro credit has less interest rate that guarantees profit

( ) SA ( ) A ( ) UN ( ) D ( ) SD

4. Micro finance banks are helpful and supportive to my business

() $\mathrm{SA}$ ( ) A ( ) UN ( ) D ( ) SD

5. Micro finance bank encourages me to save for expansion of my business

() $\mathrm{SA}$ ( ) A ( ) UN ( ) D ( ) SD

\section{MICRO CREDIT INSTITUTION AND BUSINES GROWTH}

1. Micro finance bank encourages me to save for my growing business

( ) $\mathrm{SA}$ ( ) A ( ) UN ( ) D ( ) SD

2. I borrow from micro finance banks to expand my business when necessary

() SA () A () UN () D () SD

3. My bank gives me ideas / training on areas of business expansion

( ) SA () A ( ) UN ( ) D ( ) SD

4. Micro finance banks have been very helpful in my business expansion

( ) SA ( ) A ( ) UN ( ) D ( ) SD

5. My business growth is partly attributable to my microfinance bank.

() SA ( ) A ( ) UN ( ) D ( ) SD

\section{COLLATERAL AND MICRO CREDIT}

1. microfinance bank requires collateral to lend

( ) $\mathrm{SA}$ ( ) A ( ) UN ( ) D ( ) SD

2. The collateral requirements of microfinance banks are not much

() $\mathrm{SA}$ ( ) A () UN ( ) D () SD

3. I need to save some amount of money before am entitled for loan

( ) SA ( ) A ( ) UN ( ) D ( ) SD

4. The payback time for loans is good for my business

( ) $\mathrm{SA}$ ( ) A ( ) UN ( ) D ( ) SD

5. Collateral hinderes SMEs from obtaining loans

( ) SA ( ) A ( ) UN ( ) D ( ) SD 